\title{
Karyotypic Studies in South American Lycium (Solanaceae)
}

\author{
Laura Stiefkens and L. Bernardello \\ Instituto Multidisciplinario de Biología Vegetal, Casilla de \\ Correo 495, 5000 Córdoba, Argentina
}

Accepted September 25, 1996

The cosmopolitan genus Lycium L. contains around 75 woody species that grow mainly in arid or semiarid environments (Bernardello 1986). It is included in subfam. Solanoideae that is considered monophyletic and derived (Olmstead and Palmer 1992). As it is thought for the Solanaceae in general, South America is regarded as the centre of origin of the genus and the tribe Lycieae Hunz. (Bernardello 1987). Lycium is considered older and more complex than the other two genera of the tribe (Grabowskia Schlecht., Phrodus Miers). Most of the species (51) are confined to the American continent with two centres of diversification: Arizona (USA) and Argentina (Hitchcock 1932, Bernardello l.c.). The current infrageneric classification recognizes four sections: Lycium, Mesocope, Schistocalyx, and Sclerocarpellum (Chiang 1983a, Bernardello l.c. ), although it is quite artificial and some species are not easily placed in them.

Most of the species are diploid with $n=12$, like most genera belonging to Solanoideae (Hunziker 1979). The basic chromosome number is considered $x=12$ (Bernardello 1982, Chiang 1982). Some American taxa have been already explored in their chromosome numbers (Bernardello 1982, Chiang 1982). However, there are no karyotypic studies of any species group of the genus, in spite of its importance in systematics as another morphological feature (Babcock 1947, Stebbins 1958, Jones 1970) and in the study of patterns and processes of evolution (Stebbins 1971, Levin and Wilson 1976, Bush et al. 1977). Cytological information is referred to mitotic and meiotic chromosome number reports, as it mostly happens in the family as a whole (Bernardello and Anderson 1990), except for the karyotypes of a hybrid and its parental species (Bernardello et al. 1995).

In this article, we qualitatively and quantitatively survey the karyotypes of most of the South American species of the section Lycium recognized by Bernardello (1986) with the objectives of: 1) clarifying the taxonomic relationships of the species, and 2) assessing the karyotype for possible insight into the evolution in the section.

\section{Materials and methods}

The seven species, two varieties, and 109 individuals studied with their specific collections (32) are listed in Table 1. Voucher specimens are deposited at CORD.

Mitosis in root tip cells was studied from squashes from primary roots of germinating seeds. Seeds were soaked for 1-2 days in running water, put in petri dishes on moist filter paper, and stored at room temperature in the dark. Fresh root tips were pretreated for $2 \mathrm{hr}$ in a saturated solution of paradichloro-benzene in water at room temperature, rinsed in distilled water, and fixed in freshly made ethanol:acetic acid $(3: 1)$ at room temperature for $12-24 \mathrm{hr}$. Then they were placed in alcoholic hydrochloric acid-carmine (Snow 1963) for one week. Stained root tips were stored in 50\% acetic acid until the squash was made. Meristem cells were isolated in a drop of 50\% acetic acid on a slide, macerated, squashed, and heated gently. Slides were made permanent in Euparal by means of Bradley's method (1948). 
Table 1. Lycium section Lycium taxa studied. Country, province, and place of origin of the collection, collector, and accession number are given. The number within parentheses indicates (the number of individuals studied for each accession, the number of studied cells). LB $=$ L. Bernardello, LS $=$ L. Stiefkens

L. americanum Jacq.

L. cestroides Schlecht.

L. elongatum Miers

L. infaustum Miers

L. rachidocladum Dun.

L. tenuispinosum Miers var. tenuispinosum

L. tenuispinosum var. calycinum (Griseb.) Bernardello

L. tenuispinosum var. friesii (Dammer) C. L. Hitchc.
Arg. Córdoba, Miramar, LB $733(5,22)$ and $758(5,12)$.

Arg. Córdoba, Carlos Paz, Perea w.n. $(3,10)$; Córdoba, Cosquín, LB w.n. $(6,21)$; Córdoba, Jesús María, LS $3(3,6)$; Córdoba, Córdoba, Cosa 107 (2, 16); Córdoba, Río Carnero, LB 824 (3, 13); Córdoba, Soto, LS 10 (1, 4); Jujuy, Río Perico, Barbosa $83(4,13)$ and $84(6,12)$.

Arg. Córdoba, Tulumba, LB 721 (11, 48); Córdoba, Chancaní, Toledo w.n. (4, 39).

Arg. Córdoba, after Serrezuela, A. Hunziker et al. $25389(6,37)$ and 25389 bis $(2,6)$; Catamarca, Carranza, Carabús w.n. (3, 15); Córdoba, Salinas Grandes, LB $820(1,8)$.

Chile, Coquimbo, La Serena, LB $866(4,10)$.

Arg. Córdoba, Tulumba, LB 722 (7, 17); Río Negro, Road 251 Km 104, Cocucci 442 (2, 18); Córdoba, Road $60 \mathrm{Km} \mathrm{896,} \mathrm{LB} 825$ (2, 3); La Pampa, Parque Luro, LB 114 (2, 11); Chubut, Punta Pardela, LB 784 (2, 5); La Pampa, between La Reforma y Guía 25 de Marzo, Galetto 250 (2, 4); Córdoba, Salinas Grandes, LB 278 (2, 4); San Juan, before Matagusanos, LB $836(3,5)$.

Arg. La Rioja, Chilecito, A. Hunziker 25429 (4, 49); San Juan, before Matagusanos, A. Hunziker et al. 23204 (2, 5).

Arg. Salta, El Gólgota, Barboza 80 (3, 3); San Juan, Caucete, Galetto 255 $(2,4), 256(3,2)$, and 257 (2, 3); San Juan, Vallecito, Galetto $258(2,3)$.

At least four cells per individual and 15 per species were examined. Ten to 14 metaphases of each species were photographed with phase contrast optics and Kodak PANATOMIC X film. The photographs were used to take measurements of short arm, long arm and total chromosome length for each chromosome pair. Centromeric index and arm ratio were calculated and used to classify the chromosomes after Levan et al. (1964). Satellites were classified according to Battaglia (1955). Total haploid chromosome length of the karyotype (tl), based on the mean chromosome lengths for each species, average chromosome length, and average arm ratio were calculated. In each cell, 12 pairs of homologous chromosomes were identified based on similarity in size and centromere position. Karyograms were constructed after Bernardello et al. (1994). Idiograms are based on the mean values for each taxon. Karyotype asymmetry was estimated using the indices of Romero Zarco (1986) and Stebbins' classification (1971). In addition, with data from 5 cells by species, the following indices were calculated for each chromosome: relative long arm length (RLL), relative short arm length (RSL), relative chromosome length (RL), and arm difference ratio (AD) after Watanabe et al. (1990). Based on these values, minimal chromosomal distance (MCD) and chromosomal identity (CI) were computed (Watanabe et al. 1990).

Phenograms were generated by UPGMA method using NTSYS-pc (Rohlf 1992), one based on CI values and another one based on twenty-nine variables for each species (mean length and mean arm ratio of each chromosome pair -24 var.- , both asymmetry indices, average chromosome length, average arm ratio, and genome length).

\section{Results and discussion}

The somatic chromosome number $2 \mathrm{n}=24$ was always found. According to previous data, the basic number in the tribe is $x=12$ (Ratera 1943, Khyos 1971, Di Fulvio 1977, Chiang 1982, 1983b, Bernardello 1982, 1985, Hunziker et al. 1985, Chiang et al. 1989), as it occurs in subfam. Solanoideae as well (Hunziker 1979). Like most of the Solanaceae, all species are diploid. 
Karyotype formulae obtained, total haploid chromosome length, and mean chromosome length and arm ratios are summarized in Table 2. Fig. 1 shows examples of the range of chromosomes encountered. Idiograms calculated from means are given for each taxon in Fig. 2. Table 3 shows the data matrix of $\mathrm{CI}$, whereas $\mathrm{MCD}$ was always 0 indicating there is an overall karyotypic similarity between the species.

The chromosomes are small (Table 2; Fig. 1). The average chromosome length for all the taxa as a whole is $2.01 \pm 0.18 \mu \mathrm{m}$, while the range for individual species is quite short $(1.79-2.33$ $\mu \mathrm{m}$ ). Consequently, the overall haploid genome is relatively homogeneous (range $=21.52-$ $28.01 \mu \mathrm{m}, \bar{\chi}=24.18 \pm 2.25$; Table 2 ). The shortest measured chromosome pair was $\# 11$ in samples of $L$. infaustum $(1 \mu \mathrm{m})$ and the longest one was pair $\# 1$ in a cell of $L$. rachidocladum $(3.7 \mu \mathrm{m})$. Considering the total genome length, $L$. rachidocladum has the longest while $L$. infaustum and $L$. tenuispinosum var. calycinum the shortest ones.

All the species bear one pair of $m$ chromosomes (\#1) with terminal microstatellites located at the distal end of the short arms (Table 2; Fig. 1). Satellites were frequently seen in both members of the pair, although sometimes (around $25 \%$ of the studied cells) they were detected in only one of them.

The karyotypes in this section, like those in the family (Bernardello and Anderson 1990 and cites therein), consist of $m$ and $s m$ chromosomes (11 pairs and one pair respectively; Fig. 2; Table 2). Symmetry is estimated by the $A_{1}$ and $A_{2}$ indices (Table 2). Mean values obtained for the interchromosomal asymmetry index $\left(\mathrm{A}_{2}\right)$ are quite alike for the karyotypes studied (range $=0.08-0.16$ ). This indicates there is scarce variation between the size of the different chromosomes in each species. Data for the mean intrachromosomal asymmetry index $\left(\mathbf{A}_{1}\right)$ are also comparable evidencing no sharp differences between the chromosome arms in the different taxa (range $=0.15-0.20$ ). After Stebbins' (1971) asymmetry classification, all the species' karyotypes fall into category " $1 \mathrm{~A}$ " that includes highly symmetrical karyotypes. Our data indicate that Lycium is characterized by constant, symmetrical karyotypes, as is common in Solanum and other Solanaceae (Stebbins 1971, Moscone 1989, Bernardello and Anderson 1990, Bernardello et al. 1994). In contrast to annuals, karyotypes of perennials and woody plants are very stable and less diversified (Brandham 1983, Ehrendorfer 1983), a tendency that our data support.

This study shows a high degree of intraspecific uniformity for all variables measured in the different samples studied. This lack of interpopulational variation was also observed in other solanaceous plants (Goodspeed 1954, Takehisa 1964, Moscone 1989, Bernardello and Anderson 1990), although other taxa are cytologically quite variable (Pickersgill 1977, Wu and $\mathrm{Li}$

Table 2. Lycium section Lycium taxa studied, codes, karyotype formulae, total haploid chromosome length (tl), mean chromosome length $(\mathrm{c})$, mean arm ratio $(\mathrm{r})$, and ranges of intrachromosomal asymmetry index $\left(\mathrm{A}_{1}\right)$

and interchromosomal asymmetry index $\left(\mathbf{A}_{2}\right)$

\begin{tabular}{|c|c|c|c|c|c|c|c|c|c|}
\hline \multirow{2}{*}{ Taxon } & \multirow{2}{*}{ Codes } & \multirow{2}{*}{$\begin{array}{l}\text { Karyotype } \\
\text { formula }^{\mathrm{a}}\end{array}$} & \multirow{2}{*}{$\mathrm{tl}^{\mathrm{b}}$} & \multirow{2}{*}{$c^{b}$} & \multirow[b]{2}{*}{$\mathrm{r}$} & \multicolumn{2}{|r|}{$\mathbf{A}_{1}$} & \\
\hline & & & & & & $\bar{\chi}$ & range & $\bar{\chi}$ & range \\
\hline L. americanum & amer & $11 \mathrm{~m}^{*}+1 \mathrm{sm}$ & 22.74 & 1.89 & 1.22 & 0.16 & $0.12-0.21$ & 0.12 & $0.10-0.15$ \\
\hline L. cestroides & cest & $11 \mathrm{~m}^{*}+1 \mathrm{sm}$ & 25.78 & 2.14 & 1.22 & 0.17 & $0.10-0.26$ & 0.12 & $0.08-0.16$ \\
\hline L. elongatum & elon & $11 \mathrm{~m}^{*}+1 \mathrm{sm}$ & 25.01 & 2.08 & 1.22 & 0.16 & $0.12-0.21$ & 0.12 & $0.07-0.15$ \\
\hline L. infaustum & infa & $11 \mathrm{~m}^{*}+1 \mathrm{sm}$ & 21.52 & 1.79 & 1.25 & 0.18 & $0.13-0.23$ & 0.13 & $0.10-0.19$ \\
\hline L. rachidocladum & rach & $11 \mathrm{~m}^{*}+1 \mathrm{sm}$ & 28.01 & 2.33 & 1.28 & 0.20 & $0.14-0.24$ & 0.16 & $0.12-0.20$ \\
\hline \multicolumn{10}{|l|}{ L. tenuispinosum } \\
\hline var. tenuispinosum & tent & $11 \mathrm{~m}^{*}+1 \mathrm{sm}$ & 23.63 & 1.96 & 1.21 & 0.16 & $0.14-0.18$ & 0.10 & $0.08-0.16$ \\
\hline var. calycinum & tenc & $11 \mathrm{~m}^{*}+1 \mathrm{sm}$ & 21.52 & 1.79 & 1.21 & 0.15 & $0.11-0.19$ & 0.12 & $0.08-0.16$ \\
\hline var. friesii & tenf & $11 \mathrm{~m}^{*}+1 \mathrm{sm}$ & 25.29 & 2.10 & 1.22 & 0.15 & $0.10-0.25$ & 0.12 & $0.09-0.13$ \\
\hline
\end{tabular}

${ }^{a}$ See text for nomenclature. ${ }^{b}$ Lengths in $\mu \mathrm{m}$. * One pair of chromosomes bears a satellite on the short arm. 


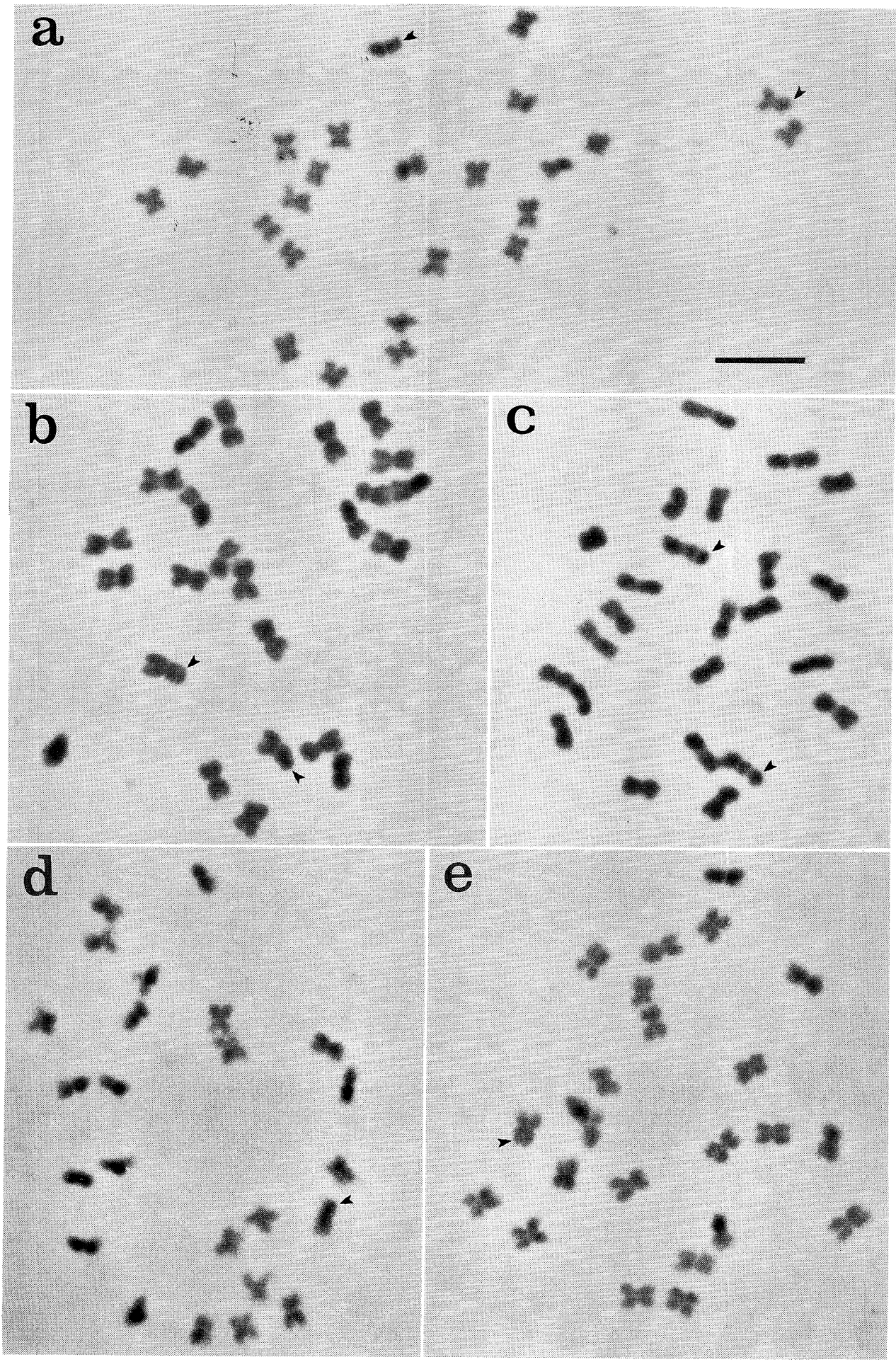

Fig. 1. Photomicrographs of mitotic metaphases of Lycium sect. Lycium roman. (a) L. infaustum (\#820). (b) L. cestroides (\#83). (c) L. tenuispinosum var. tenuispinosum (\#422). (d) L. americanum ( $\# 733)$. (e) L. elongatum $(\# 721)$. Bar $=5 \mu \mathrm{m}$, all at the same scale. Arrow heads point statellites. 
$\begin{array}{llllllllllll}1 & 2 & 3 & 4 & 5 & 6 & 7 & 8 & 9 & 10 & 11 & 12 \\ \text { amer } & \square & \square & \square & \square & 8 & 8 & 8 & 8\end{array}$

cest

elon

infa 8888888888

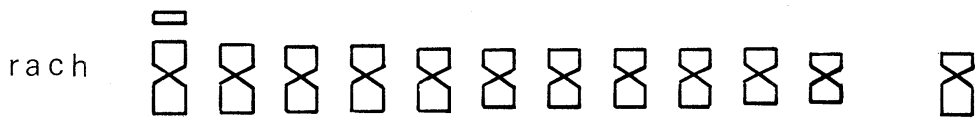

tent

tenc 88888888888

tenf

m sm

Fig. 2. Idiograms for each taxon. Bar $=1 \mu \mathrm{m}$, all at the same scale. Species codes given in Table 2.

Table 3. Data matrix of chromosomal identities of the Lycium taxa investigated (species codes in Table 2)

\begin{tabular}{lllllllll}
\hline \hline & amer & cest & elon & infa & rach & tent & tenc & tenf \\
\hline amer & 1 & & & & & & & \\
cest & 0.9 & 1 & & & & & \\
elon & 1 & 0.9 & 1 & & & & \\
infa & 0.7 & 0.7 & 0.5 & 1 & & & \\
rach & 0.6 & 0.5 & 0.7 & 0.6 & 1 & & 1 & \\
tent & 0.7 & 0.9 & 0.8 & 0.6 & 0.6 & 1 & 1 \\
tenc & 1 & 0.9 & 1 & 0.5 & 0.8 & 0.9 & 1 & 1 \\
tenf & 1 & 0.8 & 0.9 & 0.7 & 0.6 & 1 & & 1 \\
\hline
\end{tabular}



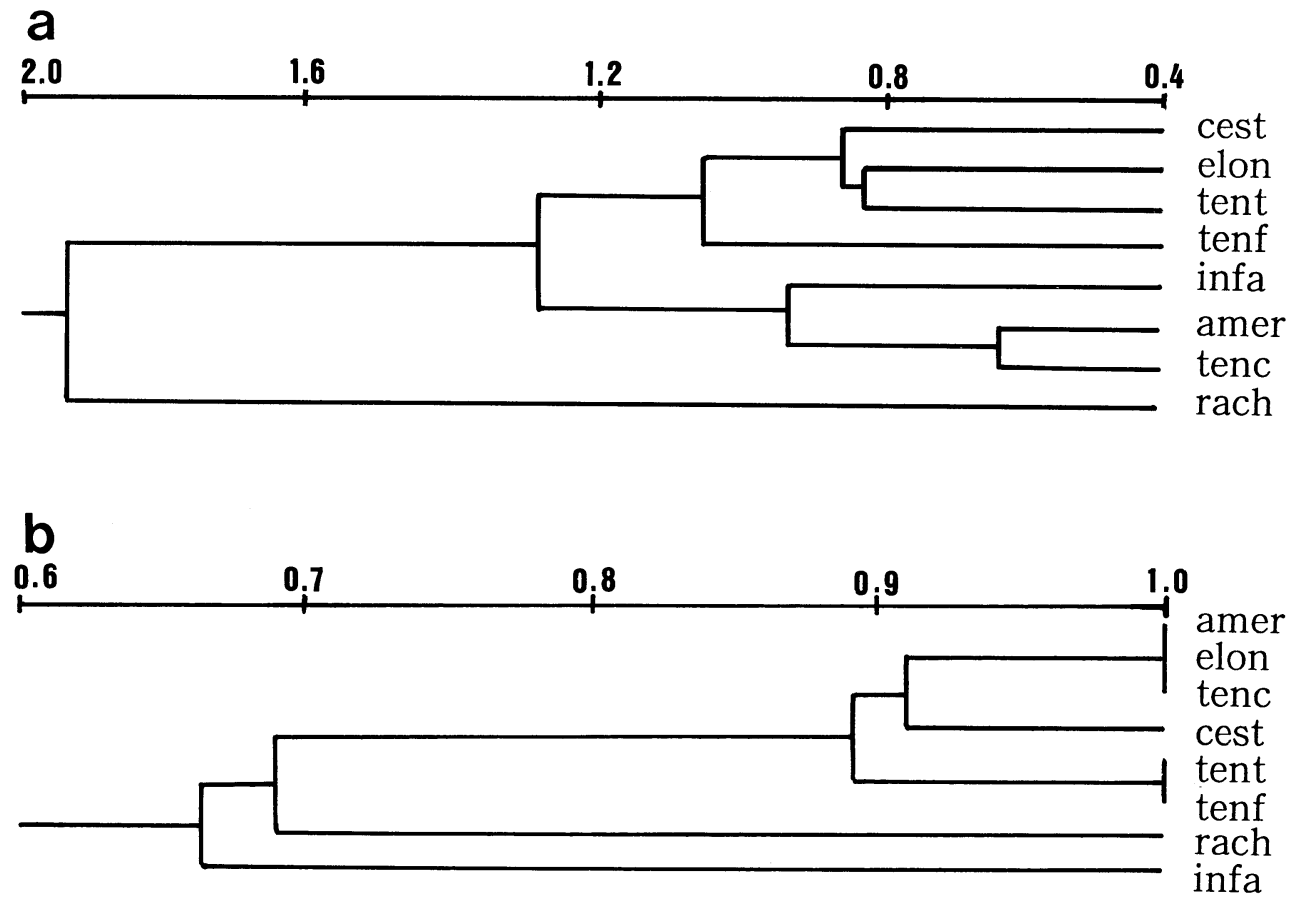

Fig. 3. UPGMA phenograms. (a) derived from average taxonomic distance (29 variables, cf. material and methods). (b) derived from CI data (Table 3). Species codes given in Table 2.

1985, Trivedi and Sinha 1986, Moscone 1990).

Karyotype composition of all the taxa is comparable. Previous data on a population of $L$. cestroides agree with our results, as well as data on L. ciliatum, belonging to sect. Schistocalyx, and the hybrid L. ciliatum $\times$ cestroides (Bernardello et al. 1995).

Cluster analysis based on 29 cytological variables grouped the species mainly according to the chromosome length (Fig. 3): 1) L. rachidocladum isolated with the longest chromosomes $(\mathrm{tl}=28.01 \mu \mathrm{m}), 2) L$. infaustum, $L$. americanum, and $L$. tenuispinosum var. calycinum with shorter chromosomes $(\mathrm{tl}=21.52-22.74 \mu \mathrm{m})$, and 3) L. cestroides, L. elongatum, L. tenuispinosum var. tenuispinosum and var. friesii with comparatively longer chromosomes $(\mathrm{tl}=23.63-$ $25.78 \mu \mathrm{m})$. A different and more realistic clustering is observed in the phenogram based on CI: most of the taxa are very close or even identical, from the cytological point of view, being $L$. rachidocladum and $L$. infaustum comparatively somewhat different.

The studied species are morphologically diverse and differentiated, as previously shown by morphological, anatomical, and phenetic studies (Bernardello 1986, 1987, Bernardello and Leiva-González 1993, respectively). However, morphological differentiation of the species of the section was not accompanied by some kind of variation in the chromosomes, a situation that differs from data on two sections of Solanum (Bernardello and Anderson 1990, Bernardello et al. 1994) and seed plants as a whole (Levin and Wilson 1976). This perspective suggests that speciation in the group has not been followed either by changes in chromosome number or by large chromosomal rearrangements. Previous meiotic studies (cf. supra) mostly reported normal bivalent formation suggesting there were not large inversions or translocations.

\section{Summary}

Mitotic chromosomes of seven South American species and two varieties of Lycium sect. 
Lycium were studied to clarify their taxonomic relationships and to assess the karyotype for possible insight into the evolution in the section. All species have $2 n=2 x=24$. The chromosome numbers of $L$. infaustum and $L$. rachidocladum are reported for the first time and data on karyotype composition are mostly new. The generalized karyotype of the section shows it is highly symmetrical. The chromosomes are metacentric or submetacentric with the formula: 11 $\mathrm{m}+1 \mathrm{sm}$. Microsatellites are present in chromosome pair $\# 1$ and are attached to the short arms. The section is karyotypically homogeneous. Cluster analysis using several cytological data and chromosomal identity index (CI) shows that most of the taxa are very close or even identical. There are no indications of major chromosomal rearrangements within the section. Karyotypic features obtained suggest that morphological differentiation in the group was not followed by chromosomal divergence.

Key words : Karyotype composition, Lycium sect. Lycium, phenetics, South America.

\section{Acknowledgements}

We thank the National Geographic Society, CONICOR (Consejo de Investigaciones Científicas y Técnicas de la Provincia de Córdoba), and CONICET (Consejo Nacional de Investigaciones Científicas y Técnicas) for financial support.

\section{References}

Babcock, E. B. 1947. The Genus Crepis. I and II. University of California Press, Berkeley.

Battaglia, E. 1955. Chromosome morphology and terminology. Caryologia 8: 179-187.

Bernardello, L. M. 1982. Estudios en Lycium (Solanaceae). II. Recuentos cromosómicos en entidades argentinas. Hickenia 1: 321-328.

- 1985. El número cromosómico de Phrodus microphyllus (Solanaceae). Bol. Soc. Argent. Bot. 24: 196-197.

- 1986. Revisión taxonómica de las especies sudamericanas de Lycium (Solanaceae). Bol. Acad. Nac. Ci. 57: 173356.

- 1987. Comparative floral morphology in Lycieae (Solanaceae). Brittonia 39: 112-129.

- and Anderson, G. 1990. Karyotypic studies in Solanum section Basarthrum (Solanaceae). Amer. J. Bot. 77: 420431.

-, Heiser, C. B. and Piazzano, M. 1994. Karyotypic studies in Solanum section Lasiocarpa (Solanaceae). Amer. J. Bot. 81: 95-103.

- and Leiva-González, S. 1993. Relaciones fenéticas entre las especies sudamericanas de Lycium (Solanaceae). Anales Inst. Biol. Univ. Nac. Autón. México, Bot. 64: 33-47.

-, Rodríguez, I., Stiefkens, L. and Galetto, L. 1995. The hybrid nature of Lycium ciliatum $\times$ cestroides (Solanaceae): experimental, anatomical, and cytological evidence. Canad. J. Bot. 73: 1995-2005.

Bradley, M. V. 1948. A method for making aceto-carmine squashes permanent without removal of cover slip. Stain Technol. 23: 41-44.

Brandham, P. E. 1983. Evolution in a stable chromosome system. In: Brandham, P. E. and Bennett, M. D. (eds). Kew Chromosome Conference II, G. Allen \& Unwin, London, England: 251-260.

Bush, G. L., Case, S. M., Wilson, A. C. and Patton, J. L. 1977. Rapid speciation and chromosomal evolution in mammals. Proc. Nat. Acad. Sci. USA 74: 3942-3946.

Chiang, F. 1982. Estudios cromosómicos en Lycium (Solanaceae) de Norteamérica. Bol. Soc. Bot. México 43: 9-23.

- 1983a. Nomenclatural changes for new sectional delimitation in Lycium (Solanaceae). Taxon 32: 456-458.

- 1983b. El número cromosómico de Grabowskia geniculata. Bol. Soc. Bot. México 45: 141-142.

Chiang, F., Viveros, R. and Mercado, P. 1989. El número cromosómico de Lycium leiospermum I. M. Johnston (Solanaceae). Bol. Soc. Bot. México 48: 145-146.

Di Fulvio, T. E. 1977. Recuentos cromosómicos en angiospermas argentinas III. Kurtziana 10: 69-72.

Ehrendorfer, F. 1983. Quantitative and qualitative differentiation of nuclear DNA in relation to plant systematics and evolution. In: Jensen, U. and Fairbrothers, D. E. (eds). Proteins and nucleic acids in plant systematics, Springer Verlag, Berlin, Germany: 3-35.

Goodspeed, T. H. 1954. The Genus Nicotiana. Chronica Botanica 16: 1-536. 
Hitchcock, C. L. 1932. A monographic study of the genus Lycium of the western hemisphere. Ann. Missouri Bot. Gard. 19: 179-374.

Hunziker, A. T. 1979. South American Solanaceae: a synoptic survey. In: Hawkes, J., Lester, R., Skelding, A. (eds). The biology and Taxonomy of the Solanaceae. Linnean Soc. Symp. Ser. 7: 49-85.

Hunziker, J. H., Xifreda, C. C. and Wulff, A. F. 1985. Estudios cromosómicos en Angiospermas de Sudamérica. Darwiniana 26: 7-14.

Jones, K. 1970. Chromosome changes in plant evolution. Taxon 19: 172-179.

Khyos, D. 1971. Lycium. In: Wiggins I., Porter D., Flora of the Galápagos Islands. Stanford University Press, Stanford: 468.

Levan, A., Fredga, K. and Sandberg, A. 1964. Nomenclature for centromeric position on chromosomes. Hereditas 52: 201-220.

Levin, D. L. and Wilson, A. C. 1976. Rates of evolution in seed plants: net increase in diversity of chromosome numbers and species through time. Proc. Nat. Acad. Sci. USA 73: 2086-2090.

Moscone, E. A. 1989. Karyotype analyses in three Patagonian and S. Andean endemic genera of Nicotianeae (Solanaceae). Pl. Syst. Evol. 166: 31-39.

- 1990. Chromosome studies on Capsicum (Solanaceae) I. Karyotype analysis in C. chacöense. Brittonia 42: 147-154.

Olmstead, R. and Palmer, J. 1992. A chloroplast DNA phylogeny of the Solanaceae: subfamilial relationships and character evolution. Ann. Missouri Bot. Gard. 79: 346-360.

Pickersgill, B. 1977. Chromosomes and evolution in Capsicum. In: Pochard, E. (ed). Capsicum 77, I.N.R.A., Montfavret Avignon, France: 27-37.

Ratera, E. L. 1943. Número de cromosomas de algunas Solanáceas argentinas (1). Revista Fac. Agron. Veterin. 10: 318-325.

Rohlf, F. J. 1992. NTSYS-pc. Numerical taxonomy and multivariate analysis system, version 1.70. Exeter Software, Setauket, NY.

Romero Zarco, C. 1986. A new method for estimating karyotype asymmetry. Taxon 35: 526-530.

Snow, R. 1963. Alcoholic hydrochloric acid carmine as stain for chromosome in squash preparations. Stain Technol. 38: $9-13$

Stebbins, G. L. 1958. Longevity, habitat, and release of genetic variability in the higher plants. Cold Spring Harbor Symp. Quant. Biol. 23: 365-378.

- 1971. Chromosomal Evolution in Higher Plants. E. Arnold, London.

Takehisa, S. 1964. The karyotype of Petunia hybrida and the differential chromosome condensation. Jap. J. Genet. 38: 237-244.

Trivedi, R. N. and Sinha, A. K. 1986. Karyomorphological studies in three populations of Solanum surattense, a weed. Cytologia 51: 157-161.

Watanabe, K., Ito, M., Yahara, T., Sullivan, V. I., Kawahara, T. and Crawford, D. J. 1990. Numerical analyses of karyotypic diversity in the genus Eupatorium (Compositae, Eupatorieae). Pl. Syst. Evol. 170: 215-228.

Wu, S. and Li, Z. 1985. Preliminary studies of chromosome morphology of several wild and cultivated eggplants. Acta Bot. Sin. 27: 361-369. 